\title{
IMPLICATURE AND PRAGMATIC POWER OF DIRECTIVE SPEECH ACT IN TEMBANG SINOM
}

\author{
Edy Tri Sulistyo \\ Arts Education Program, \\ Universitas Sebelas Maret (UNS), Indonesia \\ (Email: edytrisulistyo9@gmail.com)
}

Accepted date: 09-10-2017

Published date: 11-07-2019

To cite this document: Sulistyo, E. T. (2019). Implicature and Pragmatic Forces of Directive Speech Act in Tembang Sinom. International Journal of Law, Government, and Communication, 4(15), 301-317.

DOI: $10.35631 / \mathrm{ijl} \operatorname{lgc} .4150028$

\begin{abstract}
This study aims to find out the implicature (implicit meaning) and pragmatics in the trembling Sinom manuscript by KGPAA Mangkunagara IV. The manuscript contains 18 stanzas. The study was conducted using a qualitative paradigm, which was taken by a descriptive single case study. The data were collected from informants, places and events and documents/archives or literature. Data validity used was data triangulation. Data were analyzed by using pragmatic analysis model. The findings based on the theory of pragmatics who studied Islam and Javanese culture in the song manuscript Sinom perform some speech acts: (1) suggestion (to order) to imitate good attitude, (2) request (to invite) for humans to imitate the heroes and to be concerned and to fast, (3) permissive (to state), for example, human life must have three cases namely the noble character, wealth, and intelligence. If the three are absent, the meaning that life as a meaningless in society. The implicature and the pragmatic for the society is necessary for someone to accept exemplary, not to be wasteful, to be polite to others, to donate, and to keep up to date.
\end{abstract}

Keywords: Implicature, Pragmatic Force, Tembang Sinom, Suggestion, Request, Permissive

\section{Introduction}

Tembang Sinom is one of tembang macapat, a traditional Javanese songs belonging to tembang Jawa. The word Sinom means new shoots that grow and blossom. Sinom's song philosophy describes a man who began to grow up and has become a young man or teenager who began to grow. When they are teenagers, their job is to learn as much as possible and as high as possible so that it can become a better life in the future. From another point of view, Sinom has something to do with the word sinoman, which means youth associations to help people who are in need. There are also others who argue that the sinom relates to ceremonies for ancient youth. Even sinom can also refer to the leaves of trees that are young (bud), therefore, they are sometimes given a signal using young leaf paintings. In Serat Purwaukara, Sinom means a piece of hair which means a child of hair. 
According to Marsono, traditional Javanese song in general is functionedas a means of disclosure of the lofty values that are outlined below. The functions are as follows: (1) The function of entertainment, in relation to the form of tembangis in the form of rhymes whose the delivery is read or intoned; (2) The function of rescuing cultural norms and values, as written literature many of the old cultural norms and values which are still survived and readable in manuscripts; (3) The function of heroic generation and solidarity, for example Tripama fiber which contains ideas and messages aimed at awakening the soul of heroism and sense of solidarity; (4) Didactic function, related to the educational values in the form of the teachings human beings to be good; (5) Historical function, tells about the history of a region. For example Babad tanah Jawa, Babad Demak, Babad Pejajaran, and Babad Mataram; (6) Magical functions, reading of some tembang Macapat texts sometimes occasionally presenting salvation and offerings such as Macapat text on ruwatan; (7) Religious function, as a means of getting closer to God.

Tembang sinom literally means the young who have low profile character, sad, love to speak, however, remain optimistic about the future. Therefore, what it implies in the contentis about the advice addressed to the younger generation to seek knowledge, pursue ideals for the future (Purwadi, 2005, p. 468). The discussion of tembang Sinom refers to the manuscripts spoken by KGPAA Mangkunagara IV (king and poet in Pura Mangkunagaran Surakarta) written in 1857-1871 in the Serat Wedhatama. The Sinom tape script contains 18 stanzas and each stanza contains 9 lines.

This study was designed with a qualitative approach. This qualitative study emphasizes the cultural aspects in which there are philosophical-pedagogical values, which are understood as a picture of the social and cultural systems of the people. These values do not stand separately, but are interrelated and sustain their existence. To understand the tembang Sinom song as a result of Javanese culture, the subject of the study was centered on one area of Javanese culture as the unit analyzed as a case. This is not limiting other sources of information outside the context of the place under study. The researcher explores various sources of information even though the area outside the research location is in the sense of the results of the literature study. The source of the informant's target was the person who was assessed to know and understand information that was in accordance with the problem being studied. To choose an informant, it was initially determined by the snowball technique. This is intended to trace the source of the informant who can be questioned accurately. Sources of informants were then chosen purposively (Goetzz, J.P and Le Comte, MD, 1984).

\section{Results and Discussion}

The results and discussion of implicatures and pragmatics in the tembang Sinom of KGPAA Mangkunagara IV are included in the following.

1st stanza:

Nuladha laku utama

Tumrapé wong tanah Jawi

Wong agung ing Ngèksiganda

Panêmbahan Sénapati

Kapati amarsudi

Sudané hawa lan nêpsu

Pinêsu tapa brata
'Imitate the best attitude'

'For the people in Java'

'Noble Person from Mataram'

'Panembahan Senapati'

'A very diligent'

'Reduces air and passion'

'By way of tapa brata' 
Tanapi ing siyang ratri

Amêmangun karyènak tyasing sêsama
'In the day and night'

'Always trying to make the happiness of the hearts of others'

The prominent utterance that stand in the 1st stanza is located on nuladha laku utama, tumrap ing wong tanah Jawi, wong agung ing Ngèksiganda, Panembahan Senapati. These words can be interpreted that society nowadays need to imitate the actions of a good person. Especially, the people of Java, a good example that can be exemplified is Panêmbahan Sénapati. Panêmbahan Sénapati whose real name is Danang Sutawijaya, is the son of Ki Ageng Pemanahan. The title of Panêmbahan Sénapati is obtained when he becames king of Mataram in Java who reigned in 1575-1601. Panêmbahan Sénapati is known as the foundation of leadership in the kingdom of Mataram, in addition to having war skills, is also a figure who managed to create a set of mystics and politics. According to Damarjati, his personality as the personification of the highest understanding stage, namely manggalih means about essential matters, means aiming the arrow, about the problematic issues of life, the center of the circle, known as jangka-jangka jangkah jangkaning jaman (Synoptic texts tembang Sinom in serat Wedhatama). The example of Panêmbahan Senopati can guide Javanese people' minds. Exemplary is the hanuladha lampah utami 'imitate the good attitude'. The good attitudes that must be emulated include:

(1) kanthi têmên-têmên nyênyuda hardhaning hawa nafsu 'fight against the passions' by way of asceticism, that is always trying to make others happy (doing good deeds);

(2) tansah hambangun kautamèn 'always build virtue/do good;

(3) asring nyêpi, ngêningakên panggalih 'often alone/meditation to clear heart/mind;

(4) tansah prihatin' by way of surrender to God;

(5) tansah ngêngirangi dhahar lan néndra'fast' means to control yourself from eating and drinking, emotion, greed, wickedness, said bad thing, wasteful actions, and gossip slander;

(6) ngupadi wahyu jadmika 'seek ridha / divine grace' (Sasrahadinagara, 1995, p. 2)

Another speech that amêmangun karyènak tyasing sêsama, it can be interpreted that make the hearts of others happy through speech, sweet smiles, greetings, grammar, word choice was good, tightly to maintaining welcomed warmly, praise is appropriate, facial expression of empathy and courteous attitude to relieve Load of fellow life. The cheap and easy charity is a welcoming attitude. Better yet to share the fortune to others who are hard-earned relatives, orphans whose lives are abandoned, poor people whose lives are hard, people who are in great need, and beggars are very urgent His life. Goods alms, infak, and alms can channel equity. Especially about alms, can be a treasure, science, energy, smile, singing, prayer. Keep in mind that, the gap between rich and poor can lead to social jealousy. Therefore, the speech is an attempt to realize that others are happy and serene. With tranquillity, everyone has created the peace of society, nation and state.

The implication of this utterance is that young people need to imitate the good deeds of a person, especially someone with charisma. In this sense, the younger generation needs to learn from others either related to life experience, intelligence or science knowledge of both the world and the hereafter.

2nd stanza:

Samangsané pasamuwan

Mêmangun marta martani
'When In a meeting '

'Creating happiness spread' 
Sinambi ing sabên mangsa

Kala-kalaning asêpi

Lêlana tèki-tèk

Gayuh géyonganing kayun

Kayungyun êninging tyas

Sanityasa pinrihatin

Puguh panggah cêgah dhahar lawan néndra
'As in every moment'

'Time of the lonely'

'Wandering while imprisoned'

'For the sake of achieving the goal'

'Buried deep inside'

'Always concerned'

'Sticking to prevent eating and sleeping'

Speech that reads "nggayuh géyonganing kayun", is a prominent speech at the 2nd stanza. The speech contained kayun or karêp word, it means the will, desire, will, or ideals. The meaning of the speech is, if someone wants to achieve ideals that fit with his dreams, then should be based on effort and prayer. A person who wishes to pray to Allah, will be granted his wish, forgiven his sins, kept from danger, nourished from adversity, released from mental stress, and given his peace of mind. Allah swt. will give to someone who prays to beg for a happy life of the world and the hereafter.

Realizing the ideals or successes can be done in a way that is: maintaining health, demanding knowledge for life, improving skills / skills, seeking opportunities / opportunities to work, managing good finances, increasing unity and unity, and maintaining security stability.

The implication of this utterance is that one can obtain his desires, effort and prayer must be done. Prayer should be directed to Allah Almighty. Directly without intermediaries, in praying should be humbled and subdued. In praying, be sure if the prayer is answered, and in starting prayer should repent forgive Allah swt. by giving up all body and soul, and calling / praising God's name.

3rd stanza:

Sabên méndra saking wisma

Lêlana lêladan sêpi

Ngingsêp sêpuhing sopana

Mrih pana pranawèng kapti

Tis-tising tyas marsudi

Mardawaning budya tulus

Mêsu rèh kasudarman

Nèng tepining jalanidhi

Sruning brata kataman wahyu dyatmika

\author{
'Every left home' \\ 'Go to quiet place' \\ 'Absorb the various sciences of virtue' \\ 'In order to understand and clear the \\ intended' \\ 'The intention of the heart reach' \\ 'Sincere refinement' \\ 'Studying old science' \\ 'By the ocean' \\ 'From perseverance obtained good \\ revelation'
}

The prominent twist on this third stanza lies in the phrase lêlana lêladan sêpi 'going to a quiet place' and ngingsêp sêpuhing sopana 'absorbing the various virtues'. Both of these speeches can be interpreted that to gain good knowledge or useful both the science of the world and the hereafter. To get it needed a special time that must leave the family and the house he loved to a quiet place. Perhaps it was in accordance with the Messenger of Allah 
when he received divine revelation, he must leave his family and his home up to the mountain precisely in the cave of Hira. In the hadith it is stated that "the demand for knowledge for Muslims is mandatory; Indeed, those who seek knowledge are asked for forgiveness for him by all beings to the fish that are in the sea" (History of Abdul Barr through Anas R.A.) (Chaniago, \& Muhammad, 2016, p. 658).

The implication of the utterance that a person whether children, adolescents, adults while still alive need to seek knowledge despite having to leave the residence or the area even the country. Now, many people who seek knowledge to the country people. This is in accordance with the words of the Prophet, "Seek science even in China, for indeed seeking knowledge is obligatory upon every Muslim. Verily the angels cast their wings upon those who seek knowledge because of the good deeds of their deeds "(Ibn Abdul Barr's).

4th stanza:

$\begin{array}{ll}\text { Wikan wêngkoning samodra } & \text { 'Understand the edge of the ocean' } \\ \text { Kèdêrên wus dèn ideri } & \text { 'All of these have surrounded' } \\ \text { Kinêmat kamot ing driya } & \text { 'Stored in the liver' } \\ \text { Rinêgêm sagêgêm dadi } & \text { 'Held once a handheld' } \\ \begin{array}{l}\text { Dumadya angratoni } \\ \text { Nênggih Kangjêng Ratu Kidul }\end{array} & \text { 'Being queen' } \\ \text { nDêdêl gayuh gêgana } & \text { 'That Queen of the South' } \\ \text { Umara marêk maripih } & \text { 'Fly high into the sky' } \\ \text { Sor prabawa lan wong agung } & \text { 'Come with sneaking' } \\ \text { Ngèksiganda } & \text { 'Lost authority with noble person from }\end{array}$

Speech in the fourth stanza means that the blessing of Almighty God Panembahan Sénapati can see (dive and feel) all things happen in this world; Thus as if to live it in his senses. One day Panêmbahan Sénapati met and succeeded in defeating the South Daughter of Princess oceans, who then came to him to surrender his enormous force.

This utterance implicatures that a person who has a sharpness of heart can overcome bad traits in human beings, can even conquer spirits. To overcome lust or something unseen, then the effort must be done is to instill confidence that only the force of God can bring people to defeat it. Therefore, human beings are required to ask for help to him so that what he faces can be protected from danger.

5th stanza:

Dahat dènira aminta

Sinupêkêt pangkat kanthi

Jroning alam panglimunan

Ing pasaban sabên sêpi

Sumanggêm anyanggêmi

Ing karsa kang wus tinamtu

Pamrihé mung aminta

Supangaté tèki-tèki

Nora kétang têkên janggut suku jaja
'He asked very'

'To be intimate and be a follower'

'In the gaib world'

'At the time wandering in nature lonely'

'Ready undertakes'

'Acts which have been referred to'

'That is just ask'

'Blessingu of the hermit'

'Although it should be by way of difficulty' 
The fifth stanza is stated that because of the great desire to worship God Almighty, even though the weight and the difficulty of having to be done, the purpose is simply to ask God's pleasure to act right and holy, in accordance with His will.

The implication of this utterance is that one to get closer to God Almighty, must be based on a strong effort. In this sense, life is a struggle, to reach happiness both in the world and in the hereafter must be lived even in great pain. Devoted to God Almighty, many ways to be taken for example: (1) closer to the way to establish prayers; (2) to give something that belongs to possessions, knowledge, faces/smiles, and voice in the way of Allah; (3) detain and control lust by fasting/concerned; (4) building a relationship; Always patience in performing worship; And (5) be grateful, because everything that happens is the will of Allah swt. 6th stanza:

\begin{tabular}{|c|c|}
\hline Prajanjiné abipraya & 'The promise of good intentions' \\
\hline Saturun-down ing wuri & 'For the children and grandchildren in the future' \\
\hline Mangkono trahing awirya & 'Similarly, the royal family' \\
\hline Yèn amasah mêsu budi & 'If the search for knowledge of perfection' \\
\hline Dumadya glis dumugi & 'Eventually it will soon be achieved' \\
\hline Yeah ing sakarsanipun & 'What you want' \\
\hline Wong Agung Ngèksiganda & 'Noble person from Mataram' \\
\hline Nugrahané praptèng mangkin & 'A bless until now' \\
\hline Trah-tumêrah dharahé padha wibawa & 'All the offspring rank and authoritative' \\
\hline
\end{tabular}

The sixth stanza is also stated that whoever in his life behaves according to the will of God will undoubtedly gain happiness that can affect his offspring. It is evident that the sons and daughters of Panêmbahan Sénapati's descendants are all authoritative today and dominate the land of Java. The evidence shows that, the descendants of Panêmbahan Sénapati all have high positions in society. For example, in the Sultanate of Yogyakarta, the role of Sultan Hamengku Buwana X, in leading both in the government of Special areas of Yogyakarta and Keraton is highly respected by the people. In Surakarta, both in Kasunanan palace and in Pura Mangkunagaran, whoever becomes the top leaders in these two places always have the authority and also respected by the environment or the region.

The implication of this utterance is that one who strives to preserve the cultural or traditional values of his ancestors, is necessarily accepted by his supporters. The evidence shows that, the Government is now trying to place the traditional art as a potential area that can be developed as a booster for the State's foreign exchange. The efforts undertaken for example the art of tradition as a potential tourism, and also as a creative product that can improve the regional economy.

The 7th stanza:

Ambawani tanah Jawa

Kang padha jumênêng aji

Satriya dibya sumbaga

Tan lyan trahing Sénapati

Pan iku pantês ugi

Tinulad labêtanipun

Ing sakuwasanira

Enaké lan jaman mangkin
'Mastering the land of Java'

'All the king'

'Kstaria forceful and famous'

'There is another descendant of Senapati'

'That's worth anyway'

'In example of struggle'

'Under the ability'

'Ease in today' 
Sayektiné tan bisa ngêplêki 'Truly cannot emulate the ancient era' kuna

Speech which reads tinulad labêtanipun in the7th stanza, Mangkunagara IV requested that children imitate or emulate Panembahan decline in Senapati, although not exactly in his day. The facts show that the present era is clearly different from the era of the past. At that time to succeed one of Panêmbahan Sénapati was concerned and imprisoned in a quiet and lonely place. In the present era the effort may not be possible. Science and technology that hit in this era will answer the development of soul of young generation. Therefore, to achieve success, today's young generation can certainly do so by learning from science and technology are growing very rapidly at this time. Proverbial to be able to moon or other planet earth, people can learn astronomy, not necessarily hermit or ascetic as well as by the figures in the past. Moreover, the development of one's faith today can be said to be more religious, so to imitate the efforts or concerns made by the ancestors cannot be done by the younger generation today.

The implication of this utterance is that, although the efforts of the ancestors cannot be applied to today's conditions, one who will achieve success still needs concern, study and prayer. The concerned nature can be done by utilizing relatively small time and cost, people can gain something more. Because of the rapid development of science and technology in today's era, someone who does not want to learn it, will be out of date. Therefore, the younger generation should now study it carefully. Nevertheless, the development of advanced science and technology is not filtered with faith / religion, undoubtedly can harm him. Learning and praying is what can lead young people to success in the world and the hereafter.

8th stanza:

Low kalamun tinimbang

Ngaurip tanpa prihati

Nanging ta ing mangkya era

Pra mudha kang dènkarêmi

Anulad nêlad nabi

Nayakèng Rat Gusti Rasul

Grate ginawé umbak

Sabên séba mampir masjid

Ngajap-ajap mujijat tibaning drajat
'It's better than'

'Living without concern'

"But if in the time now '

'What is popular among young people'

'Imitating duplicate the prophet'

'Messenger of God, the Prophet'

'Used vanity'

'Every face approached the mosque'

'Expect miracles downfall degrees'

The speech pra mudha kang dèn karêmi, anulad nêlad nabi, nayakèng Rat Gusti Rasul is a prominent speech at the 8th stanza. The speech can be interpreted, that young people who live in the days of Wédhatama was written, and many are happy and mimic the attitude of the Prophet as a guide the world. For example, at that time, when going to the king, always stop at the mosque, expect mukjijad from God, may be willing to lower the high degree of grace or ask for grace / reward. In the stanza above Mangkunagara IV sharply criticized the young generation at that time who was considered unable to live as concerned as its predecessors. The younger generation at that time prefers the excessive craze in imitating a Prophet as the world's guide (the Prophet meant in this case is Muhammad saw.). The 
statement was seen on a pre mudha kang den karêmi 'preferably written by young children', anulad nêlad nabi, nayakèng Rat Gusti Rasul 'messenger of God is the Apostles'.

The penchant for imitating Rosul is good or praiseworthy because it is in accordance with the guidance. But if the passion is showcased and proudly let alone made the media to seek rank or degrees, it becomes disgraceful or not justified in religion. The phrase which reads anggung ginawé umbak 'always boast', Saben seba mampir masjid 'each facing a stop to the mosque', ngajap-ajap mujijat tibaning drajat 'expect miracles downfall degree'. The above motives in terms of religion are clearly contradictory and from the noble side also violate, therefore must be abandoned. Only the sincere, sincere and divine/divine Mercy, all the deeds done.

Implicatures of the stanza in tembang Sinom above, is still felt in public life today. Someone to do good must be sincere and seek Allah's mercy only, do not be arrogant, and do not bring religion, if the person does not practice religion perfectly. Do not like the adage jarkoni (isa ujar ning ora isa nglakoni), meaning someone who can say something and ask him to do, but he himself cannot or do not want to do it.

The 9th stanza:

\begin{tabular}{|c|c|}
\hline Anggung anggubêl saréngat & 'Always study the law' \\
\hline Saringané tan dèn-wruhi & 'Basically unknown' \\
\hline Dalil dalaning ijêmak & 'Proposition road consensus' \\
\hline Kiyasé nora mikani & "Do not understand the figurative ' \\
\hline Katungkul mungkul sami & 'They're just asleep' \\
\hline Béngkrakan mring masjid agung & 'Flocking to the grand mosque' \\
\hline Kalamun maca kutbah & 'When reading kutbah' \\
\hline Lêlagoné Dhandhanggêndhis & 'The song Dhandhanggula' \\
\hline Swara arum ngumandhang céngkok & 'The sound of melodious peal style \\
\hline Palaran & Palaran' \\
\hline
\end{tabular}

The speech "anggubêl anggung sarengat, saringané tan din-wruhi, dalil dalaning ijêmak, nora kiyasé mikani" is prominent utterance in the 9th stanza. The meaning of the speech is the following. Someone needs to study the laws of religion, though not fully understand the proposition, hadith, consensus and analogy. The meaning of the hadith is all words and deeds of Nabi Muhammad saw. Which is narrated by the Companions as the translation of the syariah, or the source of Islamic teachings after the Qur'an. What is meant consensus is a consensus of opinion of the scholars on the issue of Islamic law, whereas according to language analogy with other means to measure something and equate. In this sense the term analogy is to establish a deed that there are no legal provision other words specified by law something that has been determined the law, due to the similarities between the two (Chaniago, 2016, p.10.)

In stanza above, is studying law (syariah) is knowing the ordinance setting attitude of human life to achieve the pleasure of Allah swt. Syariah (Islamic law) is a term that exist in Islam, meaning that the regulations include worship, muamalah, munakahat, jinayat, siyasah, moral, and other regulations (Noor Salimi, 2004, p. 239). 
Explanation of the term as follows.

Worship (ibadah), namely the rules governing direct relationship with Allah (ritual), or in general worship means to include attitude in all aspects of life in accordance with the provisions of Allah swt. Which is done sincerely to get the pleasure of Allah swt. As an example of worship in the five pillars of Islam that is to say syahadatain, prayers, issued alms, fasting, and pilgrimage. But it can also do a physical worship, such as bathing, eliminating unclean, circumcision, visit the sick, hospitality, take care of the corpse, pray and others.

Tenet (muamalah), is the rules that govern one's relationship with others in terms of exchange of property (e.g., sale and purchase), for example, borrowing goods, lease, trade cooperation and others. Munakahat, ie the rules that govern one's relationship with others in family relationships, such as marriage, living arrangements, child care and others.

Jinayat, which is criminal related settings, such as the killer's, liquor and the like. Siyasah, namely concerning the problems of society (politics), such deliberation, the leadership in governance, mutual help and others similar. Morals, which regulate personal life stance, for example, gratitude, patience, humility, forgiveness, to do good to parents, and others. Other regulations, such as the eradication of poverty, the maintenance of orphans and others.

At the end of the stanza above, the speech which reads bèngkrakan mring masjid agung, it can be interpreted that enter the mosque with a sense of arrogance is not justified, because arrogance is a human act that is not liked by neighbor and God. In this connection, there are three words of Allah that is (1) "the Hereafter, We make for those who do not want to boast and do mischief in the earth. And its sequel (the good) it is for those who fear Him" (AlQashash, p.83); (2) "And walk not on earth with arrogant" (Al-Israa, p. 37); (3) "And do not turn your face from men (for pride) and walk not arrogantly on the earth. Allah does not love those who are arrogant boasting (Luqman, p 18.). In addition, one of the hadiths reads "Will you tell me about the inhabitants of hell? Everyone who's cruel, greedy and arrogant" (AlMundziri, 2005).

When becoming a khotib, it is stated in the speech"kalamun maca khutbah, lêlagoné Dhandhanggêndhis, swara arum ngumandang cèngkok Palaran" by reading his sermon sung with a twisted Dhandhanggula Palaran. The meaning of the sermon is in this sense that religious speech into a pillar in the Friday prayers and conducted by a preacher before Friday prayers in congregation begins. In delivering the sermon is okay contents sermon preacher with a song sung Dhandhanggula twisted Palaran with a view to attract the attention of his congregation. This is in accordance with the hadith of the Prophet that "Allah is Exquisite and delight in beauty. That pride is unwilling to accept the truth and insult others "shall mean the preachers here is someone in charge of delivering a lecture I sermon in between Athan Friday and congregational Friday prayers began. The sermon was delivered with the song Dhandhanggêndhis, twisted Palaran, in this case it is okay, as long as the words did not violate the religious guidance, and certainly not out of the grip has been specified.

Guidelines which need to be guided by a preacher is as follows: (1) Khutbah starts after slipping sun; (2) Khotib air during the sermon let stand in the pulpit if authorized by opening greeting, then gave thanks to Allah; (3) Khotib let sit in between the two sermons and in 
delivering his sermon let a clear voice can be heard or followed by pilgrims; (4) The khutbah let say praise to God, pronouncing blessings upon the Prophet, shahadah, intestate to himself and worshipers with / invite faithful and devoted to God, teaching things that are useful on the subject of life in the world and the hereafter, recited stanzas of the Quran, and pray for the believers and mukminat in order to get success in the world or in the hereafter on the second sermon; (5) perform ordinances Khotib let the sermon with a sequence; (6) Khotib let the holy of hadast and unclean, well-dressed, and covered her nakedness. After the sermon, the preacher leads then (as priests) to perform Friday prayers in congregation. Khotib, usually become imam (leader of prayer), as a preacher has advantages when compared to his congregation. The surplus for example in terms of expertise qiraat / reading prayers, the extent of the religious knowledge, appreciation, personality and religious experiences. As the prayer leader together, a priest at the time of establishing the prayer position is in the front and back to a congregation.

The implication of the utterance in this stanza is that if one performs a worship service it must be in accordance with its basic guidance. For example, in the religious worship of Islam, the basis of its worship is sourced from the Qur'an and Al Hadis. Implementation as directed by the Prophet Muhammad.

10th stanza:

Lamun sira paksa nulad

Tuladhaning Kangjêng Nabi

\section{O nggèr kadohan panjangkah}

\section{Watêkké tan bêtah kaki}

Rèhné ta sira Jawi

Sathithik baé wus cukup

Aywa guru alêman

Nêlad kas ngêblêgi pêkih

Lamun pêngkuh pangangkah yêkti karahmat
'Suppose that you have to imitate'

'Example of the kangjeng prophet'

'O, my son was too much that you

conjure up'

'The character cannot stand, my son'

'Because you are Javanese'

'A little is enough'

'Do not like to be flattered'

'Eager to imitate jurisprudence'

If your dream is certainly forceful mencan grace'

Utterances that stand in the 10th stanza was lamun sira paksa nulad 'Suppose that you have to emulate', tuladhaning Kangjeng Nabi 'exemplary for prophet'. It can be interpreted that, a Muslim, naturally if the filling life always trying to follow the Sunnah apostles. The meaning of the Sunnah is to follow or imitate the apostle mindset, attitude / actions, and the appearance of the Messenger. The Prophet meant here is the Prophet Muhammad, as the messenger of Allah swt. All those who think and do has been collected into a role model by the friends, known as the Prophet. In the Hadith, which are considered authentic that is set (Hadith Bukhari and Muslim). In the history it has been stated that human attitude from birth, adolescence and old until dying all have been shown exemplary. As a human being, it seems hard to practice the Sunnah of the apostle that, since the Prophet is a man of God who has the perfect nature there is no comparison. Prophet has properties that are difficult to emulate. 
The properties were as follows: (1) shidiq meaning of what was said or done properly secured; (2) The mandate means that all that was said, one should be trustworthy; (3) sermons means to be trusted to deliver the word of the divine; (4) fathanah means to have an intelligent mind and is also good in conducting the worship of Allah .; (5) aziz means to have the force of the mighty; (6) harish means wise; (7) rauf means to have forgiveness; and (8) of the uterus means to have compassion. In addition, he also has a main character that is air-dhikr, pray, strive, pray, struggle, earthy,and merciful (Mawardi, 1993, iv).

Based on the nature and character of the Prophet above, Mangkunagara IV reminded that essentially shows that as a human being, people are very heavy or difficult to imitate. But if it cannot follow the example of the Prophet as a whole, can do so in part according to their ability. Javanese for example, is still difficult to practice everything. This is in accordance with the speech $O$ nggèr kadohan panjangkah ' $\mathrm{O}$, my son your step too far', watêké tan bêtah kaki 'character cannot stand, my son', rèhné ta sira Jawi 'because you Javanese'.

Implicatures speech above is if one follows the Sunnah apostles, of course need to be tailored to the capabilities and conditions of his time. All activities every day Allah's Apostle was preaching, is different from the ordinary man has not been able to do it. Dakwah Prophet delivered to all the people, ordinary human being preaching for himself, family, and then for others.

$11^{\text {th }}$ stanza:

Nanging énak ngupa boga

Rèhné ta tinitah langip

What ta suwitèng nata

Tani tanapi agrami

Mangkono mungguh mami

Paduné wong dahat cubluk

Durung wruh cara Arab

Jawaku bae tan ngênting

Parandéné paripêksa mulang putra
'But it's nice to make a living'

'Since the doomed as weak creatures'

'Do served the king"

'Farming and trade'

'So according seems to me'

'Cause I'm a fool'

'Not to know the Arabic language'

'My Javanese language alone is not

sufficient'

'But force yourself to teach children'

Utterances that stand in the 11th stanza shown in the speech wruh cara Arab and Jawaku bae tan ngênting, KGPAA Mangkunagara IV whole heartedly realize that he is a fool; do not understand Arabic, and the Java language is also not good, but was forced to take the liberty to teach the sons and daughters of psychiatric ancestral knowledge of Java. KGPAA Mangkunagara IV, though born on earth Java and grew up in the palace that is familiar with the culture and etiquette of Java, but still feel humble.

The speech implicature is that KGPAA Mangkunagara IV invite their children to pursue themselves according to their ability, for example, in making a living, be a good employee, merchants are honest, diligent farmers and so on. In this sense, one is free to reach sky-high ideals, but be aware of the capabilities it has. 
$12^{\text {th }}$ stanza:

Saking duk maksih taruna

Sadhéla wus anglakoni

Abérag marang agama

Maguru anggêring haji

Sawadiné tyas mami

Bangêt wêdiné ing bésuk

Pranatan akir jaman

Tan tutug kasêlak ngabdi

Nora kobêr sêmbahyang Gya tinimbalan
' Since when was young'

'Although briefly have suffered'

' Studying religion'

'Studied according to the rules of Hajj'

'Actually, the secret of my heart'

'It's fear of the future and then'

'The rules at the end of time'

'Unfinished trigger devoted'

'No time prayer has been calling'

The speech in pupuh Sinom $12^{\text {th }}$ stanza described the experiences KGPAA Mangkunagara IV when he was a teenager. The experience especially when studying religion as stated in the speech abérag marang agama, based on the fear of the torments of hell in the hereafter. But unfortunately, what was done was not able he finished it, because by the time devoted to the king, every time you call often, even sometimes during the middle establish the prayer.

The speech implicature is that humans when they live needs to prepare himself to face the real life that is the life hereafter. The preparation can be done by faith and Air piety to God Almighty. Being a believer means, trust Oneness and attributes of God, faith in angels, faith in the scriptures, faith in the Apostles, the faith in the Last Day (of Judgment), and faith in the decree. Humans are required to devoted, that is to say away from the prohibitions of God and carry out all the commandments and follow the guidelines conducted by the Apostles. If it is done, then in the hereafter place in heaven.

13th stanza:

Marang ingkang asung pangan

Yèn kasuwèn dèn-dukani

Bubrah bawur ing tyasingwang

Lir kiyamat sabên ari

Bot Allah apa Gusti

Tambuh-tambuh solahingsun

Lawas-lawas grahita

Rèhné ta suta priyayi

Yèn muriha dadi kaum têmah nistha

\author{
' To that feed' \\ ' If too long scolded' \\ ' Screwed-turvy my heart' \\ ' Just as the apocalypse every day' \\ ' Heavy God or Gusti' \\ 'Hesitant actions' \\ 'After a long time unthinkable' \\ ' Because children royals'
}

'If only want to be an interpreter of prayer

is contemptible'

The speech in pupuh Sinom13th stanza meant that when KGPAA Mangkunagara IV did not come immediately when called king, then he gets angry. There are two choices facing in mind that to be students (studying religion) or obedient to the king, which means heavy on employment obligations which gives a mouthful of rice. Finally, KGPAA Mangkunagara IV realized if he was was the son of nobles and believes not in place if he is to be students. However, what he has done it already got a reward from the Lord, because they act both slightest certainly paid off. This is in accordance with the understanding clue giver will be rewarded goodness, "He who gives instructions goodness, then for him will get a reward like the reward earned by those who followed him, and did not diminish at all the rewards (AlMundziri, 2005) 
This speech implicature are young people like living in this modern age, full of challenges as a result of this influx of information technology, and there should be shielded her that religion. Learning science and religion is obligatory for every man, "He who goes to study, then Allah will facilitate for him the way to heaven (Al-Mundziri, 2005)"

14th stanza:

Tuwin Ketib suragama

Pan ingsun nora winaris

Angur aged ngantêpana

Pranatan wajibing urip

Lampahan anglêluri

Aluraning pra lêluhur

Kuna-kumunanira

Kongsi tumêkèng samangkin

Lyan tan Kikisané amung ngupa boga
'And if it becomes Ketib interpreter mosque prayer'

'I do not have the right'

'Better interested in earnest'

' Rule mandatory for life'

' Run and inherit'

' Traces of the ancestors'

'Since long ago'

'Up to now'

' Finally, another not only make a living'

The speech in pupuh Sinom $14^{\text {th }}$ stanza explained that KGPAA Mangkunagara IV realized if the talents and expertise of its interpreter religion. Therefore, he decided to still fulfill the obligation to serve and worship the ancestors of the first up at that time. So, keep in mind, is to put yourself on the livelihood and life with an attitude of virtuous conduct, such as those done by his ancestors since time immemorial. Virtuous, synonymous with the character, the attitude and human attitude which is based on the activity of thinking or if the inner.

Ki Hajar Dewantara states that morality is a social attitude of a person based on maturity (Endraswara, 2006, p.2-3). Noble character means the attitude and attitude of a person-based soul and aligned with the social norms prevailing in society. Virtuous if it is associated with religious insight is called akhlakul karimah (noble attitudes and actions). This attitude is reflected in aspects of life that includes religious values, customs, and manners of attitude etc.

According to Character Development Team Yogyakarta province formulated 12 noble character traits: (1) service; (2) honesty; (3) courtesy; (4) tolerance; (5) discipline; (6) sincerity; (7) responsibility; (8) harmonious; (9) stay calm; (10) empty boards; (11) manners; and (12) of mutual cooperation (Ibid, p.7). All 12 of these traits, more directed at horizontal relationships are relationships between people and their fellow human beings, however, also teach religion. Other aspects relating to the vertical relationship, the relationship with God, for example, characterized by: piety, remember the God, trust, repent, be grateful, and jihad.

Implicatures of speech in pupuh Sinom14th stanza which humans live in this world, should set the balance in his life in this world and in the face of a new life for the future (hereafter).

$15^{\text {th }}$ stanza:

Bonggan kang tan mrêlokêna

Mungguh ugêring ngaurip

Uripé lan tri prakara

Wirya arta tri winasis
'One of their own do not care'

'Will the rules of life'

'Living grounded in three cases'

'Sublime, treasure and clever' 
Kalamun kongsi sêpi

Saka wilangan têtêlu

Têlas tilasing janma

Aji godhong jati aking

Têmah papa papariman ngulandara
'If until not have'

'From the number three'

'Screwed human sense'

'More precious teak leaf dry'

'Finally, miserable as beggars wandering'

The speech in pupuh Sinom of the $15^{\text {th }}$ stanza stated that the lives and livelihoods of people in this world are always in touch with three kinds (three terms of life in the world). This is in accordance with the speech uripé tri prakara, and he conceded arta tri winasis.

It consists of three requirements: (1) he conceded, means trying to work to achieve a viable position in accordance with the capabilities and performance to bring the life source of income (salary, purchase etc.); (2) Assets, means trying to get the capital money's kosher bit by bit, in order to trade, farming, or carpentry, and so on; and (3) Scholar (Winasis), means trying to gain knowledge (skills) both rough and smooth, which carries the source of life. If all three conditions are ignored or not implemented, then his life in this world it's no use. It is like aji godhong jati aking and têmah papa papariman ngulandara, means a worthless life and eventually became homeless as a beggar.

Implicatures speech is a human life should have the knowledge or skills, eager, and willing to work to accumulate wealth, so they have the status or position in society, as intelligent (educated) are useful for the community, or perhaps the rich are generous, so he will be respected in the community. If it works, he needs to show the nature of professionalism, so that everything is done to give account.

16th stanza:

Kang wus waspada ing patrap

Mangayut ayat winasis

Wasana wosing jiwangga

Mêlok tanpa aling-aling

Kang ngalingi kalingling

Wênganing rasa tumlawung

Kèksi saliring jaman

Angê langut tanpa têpi

Yèku aran tapa tapaking Hyang Sukma
'That has been wary of attitude'

' Living the wise rule'

'Finally, the essence of life'

'It looks real with no curtain'

'The cover exposed'

'The opening of the taste that much'

'It appears the whole time'

'Far indefinitely'

'Known Hyang meditated on the site

Sukma'

In $16^{\text {th }}$ stanza there were utterances that stand the kang wus waspada ing patrap. In the speech contained the most prominent word patrap, which means attitude, conduct, way of doing. Meaning that more speech is someone who has been able to master how to act or behave appropriately, it will be able to experience the great things and can keep abreast of the times. Therefore, patrap here considered as a vehicle to deliver the journey towards the goal of life has aspired. Briefly, patrap can be interpreted as a way of acting or attempt to achieve certain goals.How to behave (attitude) someone in this stanza is the patrap seating (lenggah), meaning do with cross-legged, upright body with tasty (not forced) and not tense and not bulging eyes.

In the stanza, there is also speech kang ngalingi kalilin, meant that when the air patrap / business person is correct, then the soul can know the situation and know also all that surrounds his personal self. At the end of this stanza, there are two different words meaning 
the soul and in the heart. The soul is the form of someone's body that is thinking and feeling, while sukma (heart) is life-giving. In this sense, in the heart nobler than the soul.

Implicatures speech on pupuh Sinom stanza of the 16th implementation can be seen in four sêmbah in pupuh Sinom includes sêmbah raga, sêmbah cipta, sêmbah jiwa, and sêmbah rasa.

$17^{\text {th }}$ stanza:

Mangkono janma utama

Tuman tumanêm ing sêpi

Ing sabên rikala mangsa

Masah amêmasuh budi

Lairé anêtêpi

Ing rèh kasatriyanipun

Susila anoraga

Wignya mèt tyasing sêsami

Yèku aran wong barèk bêrag agama
'That's main man'

'Like nature lonely'

'In each time period'

'Sharpen and cleanse the mind'

'Meet the circumstances'

'As a human knight'

'Polite and humble'

'Clever take heart fellow'

'That is called the advanced field of religion'

Speech in pupuh Sinom 17th stanza mainly reads mangkono main Janma, KGPAA Mangkunagara IV shows that the main human / virtuous are those who always make a habit of inner silence. Outward always fulfills the obligations of community life and perform his duties in an orderly, polite / humble, always pleasing others, and always keep their promises.

This speech implicature is someone whose life thinking about community needs to be based in religion. This can be done by way of trust to God Almighty. Trust means surrender whole heartedly or surrender to Allah. This understanding can be explained that tawaqal is accompanied by actions and expectations with a quiet heart, peaceful soul, and a strong belief that what desired by Allah. Inevitable, what does not desire for it will not happen and Allah do not waste the reward of those who do good.

$18^{\text {th }}$ stanza:

Ing jaman mêngko pan ora

Arahé para taruni

Yèn antuk tuduh kang nyata

Nora pisan dènlakoni

Banjur jujurkên kapti

Kakèkné arsa winuruk

Ngandêlkên gurunira

Pandhitané praja sidik

Tur wus manggon pamucungé mring makripat
'In the present era is not so'

'Directions motion of the young'

'If the user gets a real'

'Never executed'

'Then, of its own volition'

'His grandfather would be taught'

'Relying comrade teacher'

'Reverend clever country'

'Have lived and came to gnosis'

Speech " ing jaman mengko pan ora" in stanza Sinom $18^{\text {th }}$ stanza showed that today, the young rarely bother teaching needs and considered important. Although it has got it and pledged to carry it out, but it disregards, even otherwise considered himself more than old 
people are saying classic and stodgy. Or if not so it relies on the teacher who gives supernatural teachings outward.

Implicatures speech above, is associated with responsibility, especially in the younger generation at the time the speech was delivered and apply today. Every human being has the responsibility of each, meaning that what is done is not only accountable to the people, but the main one is precisely to God. Related to this sense the following note this hadith.

"You are the leader, and you are all responsible for the principals. An imam (leader) is as a shepherd who will be questioned about his boss, and a woman / housewife (wife) is a leader in the house of her husband that he would be asked about the results of his leadership. A maid (waitress, assistant) is to become a leader in ostanzaeing the property of his master, and he is responsible (to be asked) of things leaders. A child is father's property supervisor that he will be asked about his watch, then you all are leader and you all will be asked about his attention (Al-Mundziri, 2005).

\section{Conclusion}

Based on the findings and discussions related to implicatures and force pragmatic song Sinom concluded that there are three action said dominant namely speech act: (1) suggestion (to rule) for example in the sentence nuladha laku utama'imitate the attitude of the best', in this case someone let only speak only things that are good or better still. Another good deed to another exempliified among other: good morals, doing good to the neighbors, do good to the children, do good to his wife, the act gives better than the requestor; (2) request (invite) on speech aniatyasa pinrihatin 'always concerned" to humans in order to imitate the fighters and valid concern and fasting during Ramadan and fasting three days each month, fasting six days in Shawwal; (3) permissive (states) in the speech uripe lan tri prakara, wirya arta tri winasis ' life based on three cases that virtue, wealth, and intelligence. Magnanimity can be equated with good morals, that is to say the best of human beings is the nicest guy moral or degree/position of a person lies in his attitude. Another case with wealth, real wealth is not because it has a lot of wealth, but the real wealth is the wealth of life, meaning that even if fortune abound but narrow his soul he will not be happy. Treasure a bit more reassuring and if there are remaining after being worn for daily necessities directly wherewithal to others who are in need. As for intelligence or have a good knowledge on the side of Allah. is a useful and taught to others. The third speech, actions to take human lives to emulate best attitude, human life should have three cases the noble character, wealth, and intelligence. When all three cases mentioned are not owned life was not worth in society. Therefore, a person living in the community must be willing to accept exemplary from others, not reioice, courteous to others, like charity, and keep abreast of the times.

\section{References}

Ahmadi, Abu \& Noor Salimi. (2004).Dasar-dasar Pendidikan Agama Islam untuk Perguruan Tinggi. Jakarta: PT Bumi Aksara,

Al-Mundziri, Al-Hafidz Zakiyuddin abul adziim, Mukhtasar Shahih Muslim, Hadis no.22, Cet.VII, Kuwait:Jam'iyyah Ihya' at-Turats al-Islami, 1426H/2005M

Ardani, Moh. (1995). Al Qur'an dan Sufisme Mangkunagara IV (Studi Serat-Serat Piwulang). Yogyakarta: Dana Bhakti Wakaf,

Chaniago A., \& Muhammad, B.H. (2016). Indeks Hadits dan Syarah. Jakarta: CV. Pustaka Kalbu,

Endraswara, Suwardi. (2006). Falsafah Hidup Jawa. Yogyakarta: Penerbit Cakrawala,

Endraswara, Suwardi.(2006). Budi Pekerti Jawa Tuntunan Luhur dari Budaya Adiluhung. Yogyakarta: Buana Pustaka 
Goetzz, J.P \& Le Comte, M.D., (1984). Ethnography and Qualitative Design in Educational Research. New York: Academic Press

Nawami, Imam. (1999)..Riyadhus Shalihin ( Vol. 1 dan 2). Jakarta: Pustaka Amani,

Hadisutjipto, S.Z. (1975). Serat Wedhatama. Jakarta: Pradnya Paramita dan Yayasan Mangadeg

Jatmiko, Adityo. (2005). Tafsir Ajaran Sêrat Wédhatama. Yogyakarta: Pura Pustaka Lubis, Hamid Hasan A. (1991). Analisis Wacana Pragmatik. Bandung: Penerbit Angkasa.

Mardanus, Sosrohadinagoro, S. RMT. (1995). Wedhatama Winardi "Wedaran Serat Wedhatama” A. 905. Surakarta: Reksa Pustaka Mangkunagaran

Mawardi Labay El Sulthani.. (2002). Zikir dan Doa. Jakarta: Al-Mawardi Prima.

Rasyid, Sulaiman H. (1998). Fiqih Islam (Hukum Fiqh Lengkap).Yogyakarta: Sinar Baru Algensindo.

Sasrahadinagara, RMT S. M.. (1995). Wedhatama Winardi "Wedaran Serat Wedhatama” A. 905. Surakarta: Reksapustaka Mangkunagaran

Sastrawardaya.t.t. Wédhatama Makna dan Artinya. Koleksi perpustakaan Reksa Pustaka Mangkunagaran A 616.

Satyapranawa, R.Ng. dan Sarjana Darmasarkara, KRT. (2000). Bahasan dan Wawasan Atas Sêrat Wédhatama Karya KGPAA Mangkunagara IV. Surakarta: Reksa Pustaka Mangkunagaran.

Setiyoko, Fajar. (April 17, 2016). Kumpulan Tembang Macapat Lengkap dengan Penjelasan Serta Contohnya.Retrieved from: kampoengilmu.com/tembang-macapat/

Simuh. (2002). Sufisme Jawa Transformasi Tasawuf Islam ke Mistik Jawa. Yogyakarta: Bentang Budaya

Soedjonoredjo, R. (1982) Wédhatama Winardi. Cetakan1. Surabaya: Penerbit CV Citra Jaya. Soedjonoredjo, R. (1985. Wédhatama Winardi. Cetakan 2. Surabaya: Penerbit CV Citra Jaya Sulistyo, Edy Tri. (2012). Kajian Tindak Tutur Direktif dalam Serat Wedhatama karya KGPAA Mangkunagara IV. Disertasi. Surakarta: Pascasarjana UNS 